\title{
Perspektif Sosiologi Agama" (Kerukunan Antar Umat Beragama Dalam Peringatan Hari Besar Keagamaan (PHBA)
}

\author{
Abdul Aziz ${ }^{1}$ Ahmad Muhajir ${ }^{2}$ \\ IAI Darussalam Blokagung Banyuwangi ${ }^{12}$ \\ Email: abdulaziz@iaida.ac.id ${ }^{1}$, ahmadmuhajir@gmail.com ${ }^{2}$
}

\begin{abstract}
Religious life in a society is an important life that contains activities both between human relationships, individuals or groups, as well as human relations with God. From the above background, the focus of the problem in this study is: How are the forms of harmony carried out by the people of Sumbermanggis Hamlet so that there is harmony between religious communities in commemoration of religious holidays. In answering these problems the researcher used a qualitative research approach with data collection tools, namely: interviews, participant observation and documentaries, and the data that had been collected was corrected using triangulation data analysis. From the results of this study it is known that the forms of harmony between religious communities in commemoration of religious holidays in Sumbermanggis Hamlet include visiting each other or silaturrohim (communication), and mutual respect or appreciation (interaction) of other religions. By realizing it, the interaction is in the presence of mutual respect and respect when one of the religions commemorates a religious holiday, and communication relationships that are manifested by salingsilaturrohim and mutual visits to the homes of people of different religions who are carrying out religious holidays.
\end{abstract}

\section{Key words: Inter-Religious Harmony, Commemoration of Religious Holidays}

\begin{abstract}
Abstrak
Kehidupan keagamaan dalam suatu masyarakat merupakan suatu kehidupan penting yang mengandung aktivitas-aktivitas baik hubungan antar umat manusia, individual atau kelompok, maupun hubungan manusia dengan Tuhannya. Dari latar belakang diatas maka focus masalah dalam penelitian ini adalah: Bagaimana bentuk-bentuk kerukunan yang dilakukan oleh masyarakat Dusun Sumbermanggis sehingga terjadi kerukunan antar umat beragama dalam peringatan hari besar keagamaan. Dalam menjawab permasalahan tersebut peneliti menggunakan pendekatan penelitian kualitatif dengan alat pengumpulan data yaitu: wawancara, observasi partisipan dan dokumenter, serta data yang sudah dikumpulkan dikoreksi dengan menggunakan analisis data trianggulasi. Dari hasil penelitian ini diketahui bahwa bentuk-bentuk kerukunan antar umat beragama dalam peringatan hari besar keagamaan di Dusun Sumbermanggis meliputi
\end{abstract}

18 | Perspektif Sosiologi Agama” (Kerukunan Antar Umat Beragama Dalam Peringatan Hari Besar Keagamaan (PHBA) Abdul Aziz, Ahmad Muhajir 
saling berkunjung atau silaturrohim (Komunikasi), dan saling menghormati atau menghargai (Interaksi) terhadap pemeluk agama yang lainnya. Dengan diwujudkan, Interaksi dengan adanya saling menghargai serta menghormati ketika salah satu agama ada yang memperingati hari besar keagamaan, dan Hubungan komunikasi yang diwujudkan dengan salingsilaturrohim serta saling sambaing kerumah warga yang berbeda agama yang sedang melaksanakan hari besar keagamaan.

Kata-kata kunci : Kerukunan Antar Umat Beragama , Peringatan Hari Besar Keagamaan

\section{A. Latar Belakang}

Kehidupan keagamaan dalam suatu masyarakat menupakan suatu kehidupan penting yang mengandung aktivitas-aktivitas baik hubungan antar umat manusia, individual atau kelompok, maupun hubungan manusia dengan Tuhannya.

Berdasarkan Undang-undang maupun dari dasar Negara sangat jelas, bahwa kehidupan beragama itu dilindungi dan dijaga oleh Negara itu sendiri. Menurut undang-undang dasr 1945, Negara ini melindungi dan menjamin segenap penduduknya untuk memilih suatu keyakinan yang menurutnya aitu adalah sebuah kebenaran menurut hati dan nuraninya. Hal itu disebutkan dalam undang-undang dasar 1945 pasal 29 ayat 2 yang berbunyi "Negara menjamin kemerdekaan setiap penduduk untuk memeluk agamanya serta untuk melakukan ibadah dengan keyakinan dan juga kepencayaan dari seorang diri tersebut.

Kebebasan beragama yaitu kebebasan manusia untuk meilih dan memeluk suatu keyakinan yang diyakini kebenarannya serta dilandasi dari hati nurani dan akal. Kebebasan beragama berkaitan dengan keyakinan hidup untuk memilih agama dan menjalankan ajaran yang terkandung di dalamnya, guna untuk mengatur hidup sebagai pribadi anggota masyarakat, warga Negara dan tentunya khalayak sedunia. Aspek lain yang termasuk dalam kebebasan beragama adalah kebebasan untuk menjalankan peribadatan sesuai dengan ajaran yang dianutnya. Perlindungan terhadap perasaan keagamaan yanti tertuang dalm keyakinan serta yang dianutnya (Tuhan dan Kitab Suci, perlindungan

19 | Perspektif Sosiologi Agama” (Kerukunan Antar Umat Beragama Dalam Peringatan Hari Besar Keagamaan (PHBA) 
tempat ibadah dan sarananya, perlindungan juga terhadap pemuka agama itu sendini, serta kebebasan untuk melakukan dakwah.

Hubungan antara manusia dengan agama merupakan suatu hubungan totalitas atau dalam pengertian lain yaitu bagaimanapun manusia tidak bisa dipisahkan dengan agama, namun karena agama yang dianut oleh manusia di dunia ini tidak hanya satu, namun beragam agama, untuk itu kebenaran dari masing-masing agama yang dianut oleh setiap orang itu muncul kepermukaan.

Agama yang ada di Negara dan resmi diakuinya ada beberapa agama, yakni agama islam, Kristen protestan, Kristen katolik, Hindu, Budha, serta Konghucu. Sungguh hal tersebut jelas berbeda tetapi tidak terpisahkan, yakni saling berhubungan atau mempengaruhi, tumpang tindih antara satu dengan yang lain. Dengan ungkapan lain ketika satu aspek dibahas maka aspek yang lain juga berada di dalamnya. Realitas interaksi tersebut mernungkinkan baik secara internal maupun eksternal terjadinya suatu perubahan atau perkembangan tindakan beragama, yakni adanya kerukunan antar umat beragama.

Beragama tidak terlepas dari kepercayaan dan system keyakinan yang ditanamkan atau dikembangkan di kalangan mereka masingmasing. Dengan demikian praktek keagamaan ini bisa berupa dua hal yang tidak terpisahkan walaupun berbeda. Pertama, pelaksanaan seperangkat ritus oleh penganutnya baik berupa ketetapan pelaksanaannya tentang tempat, waktu, cara, pernimpin, benda-benda atau peralatan yang digunakan. Kedua, adalah ketaatan orang dalam menjalankan setiap keyakinan seperti ritus secara tekun, konsisten dan menjalankan cara-cara yang dinilai memiliki nilai ibadah yang lebih tinggi.

Bertambahnya pengetahuan dan pengalaman keagamaan seseorang baik dalam bentuk perluasan dan pendalaman maupun pengenalan akan perbedaan-perbedaan pemahaman ajaran agama, tidak mustahil 
berakibat terjadinya kerukunan antar umat beragama dan memiliki makna sosial tertentu.

Secara hakiki, manusia itu makhluk social sejak dilahirkan, dalam kehidupan, manusia selalu mebutuhkan orang lain untuk memenuhi segala kebutuhan. Unsur yang sangat penting kebudayaan adalah kepercayaan atau keyakinan yang merupakan konsep manusia tentang segala sesuatu disekelilingnya. Maka keyakinan itu menyangkut gagasan manusia tentang individu, orang lain, serta bebagai pihak yang berkaitan dengan social dan dunia supranatural. Kepercayaan adalah gelaja yang sangat bersifat intelektual terhadap kenyataan dari kebenaran suatu pendapat.

Masyarakat adalah suatu kesatuan yang utuh, terdiri dari beberapa individu yang hidup di suatu wilayah atau daerah tertentu, yang mana masyarakat itu diperintah oleh pemerintahan suatu Negara, dan masyarakat merupakan bagian dari suatu Negara itu sendini.

Kemajemukan agama merupakan realita, kekayaan dan anugerah yang patut di sykuri untuk menciptakan kerukunan. Namun kemajemukan itu di sisi lain dapat mengundang kerawanan social yang dapat mengganggu antar umat beragama serta mengancam kesatuan dan persatuan bangsa apabila hal ini tidak disikapi secara bijaksana. Dengan demikian, kemajemukan agama dan keyakinan tidak hanya dijamin oleh konstitusi Negara saja, melainkan menupakan rahmat Tuhan yang Maha Esa yang harus tetap dijaga serta dipertahankan oleh setiap pemeluk agama tersebut.

Konsep kerukunan antar umat beragama pernah dirumuskan dan ditetapkan oleh pemerintah orde baru dengan melibatkan semua tokoh agama-agama yang ada di Indonesia. Oleh karena itu perlu adanya kajian terhadap konsep kenukunan antar umat beragama yang selama ini diterapkan pemerintah, ia tidak lagi hanya sebagai bungkus formal dari kenyataan fluralitas agama di Indonesia, tetapi harus menjadi motifator bagi terbentuknya kesadaran beragama dan berteologi di Indonesia. Jika 
tidak, maka konflik antar agama tidak bisa terhindarkan, akan selalu meledak. Bila terjadi hal ini akan menghancurkan sendi-sendi kehidupan berbangsa dan bernegara, baik aspek politis, ekonomi maupun sosial budaya.

Kerukunan merupakan suatu sarana yang harus ada sebagai “condition sine qua non” untuk mencapai tujuan lebih jauh yaitu situasi aman dan damai, situasi ini amat dibutuhkan semua pihak dalam masyarakat untuk memungkinkan penciptaan nilai-nilai spiritual dan material yang sama-sama dibutuhkan untuk mencapai tingkat kehidupan yang lebih tinggi. (Hendropuspito, 2006 : 170)

Agar kerukunan hidup antar umat beragama menjadi etika dalam pergaulan kehidupan beragama, Hugh Goddard, seorang kristian Inggris yang ahli teologi Islam, mengatakan : demi kerukunan antar umat beragama harus dihindari penggunaan "standar ganda" (double standars) orang-orang Kristen ataupun Islam misalnya, slalu menerapkan standar-standar yang berbeda untuk dirinya; biasanya standar yang ditunjukkan bersifat idial dan normative. Sedangkan terhadap agama lain mereka memakai lain yang lebih bersifat realitistis dan histories. Melalui standar ganda inilah muncul prasangka-prasangka teologis yang selanjutnya memperkeruh suasana hubungan antar umat beragama. Ada tidaknya keselamatan dalam agama lain, sering kali ditentukan oleh pandangan mengenai standar ganda . Keyakinan bahwa agama sendiri yang paling benar karena berasal dari Tuhan sedangkan agama lain hanyalah kontruksi manusia, merupakan contoh dari standar itu. Demi terciptanya hubungan eksternal pemeluk antar agama perlu dilakukan dialog antar agama, sedangkan untuk internal agama diperlukan reinterprestasi pesan-pesan agama yang lebih menyentuh kemanusiaan yang universal dalam hal ini, peran tokoh agama mesti lebih dikedepankan. (Dadang Kahmad, 2002 : 175-176)

Kerukunan antar umat beragama di zaman sekarang tidak dapat dielakkan dengan beberapa perkara antara lain. Kehidupan dalam 
masyarakat tertutup yang dihuni satu golongan pemeluk satu agama yang sama, tetapi dalam masyarakat, dimana komunikasi dan hidup bersama dengan golongan beragama lain tidak dapat ditolak demi kelestarian dan kemajuan masyarakat itu sendiri. Dengan kata lain, hidup dalam masyarakat pural dari kepencayaan maupun kebudayaannya. Kalau keharusan untuk menciptakan masyarakat agama yang berjiwa kerukunan atas desakan dari ajaran agama akan dikesampingkan atau tidak dihiraukan, maka mau tidak mau akan dihadapkan kepada situasi lain. oleh karena itu akan dituntut oleh situasi untuk bekerja sama dengan semua pemeluk agama untuk bersama-sama menjawab tantangan baru yang berukuran nasional. Kesemuanya itu tidak mungkin diatasi oleh satu golongan agama tertentu, tetapi membutuhkan konsolidasi dari segala kekuatan baik moral, spiritual, maupun material dari semua umat beragama. (Hendropuspito, 2006 : 172)

Dengan kerukunan antar umat beragama yang kokoh, maka diharapkan tidak terjadi hal-hal atau permasalahan yang menyangkut konflik antar umat beragama, dan kondisi tersebut bisa dijadikan wawasan untuk mengembangkan kerukunan secara dinamis. Namun ada lagi hal lain, yakni keharmonisan hidup antar umat beragama juga sangat perlu dibina serta dipelihara pada masa-masa mendatang dengan lebih menitik beratkan pada dialog keagamaan serta kesediaaan melakukan komunikasi antar umat beragama antara satu dengan yang liannya.

Kerukunan itu mempunyai peran sangat penting dan sangat besar untuk menjaga kehidupan yang akrab antar umat beragama dengan saling menghormati, saling menghargai, serta melindungi satu sama lainnya, sehingga kehidupan yang harmonis dan dinamis ini dapat terwujud dengan baik. Berbagai upaya dilakukan dalam rangka menjaga kerukunan antar umat beragama, antara lain dengan pertemuan secara berkesinambungan antara took-tokoh pemuka agama yang mempunyai 
pengaruh yang besar dalam masyarakat. Disamping itu, juga harus ada kesadaran dan pengertian antara satu dengan lainnya.

Pentingnya kerukunan adalah untuk mewujudkan kesatuan pandangan yang membutuhkan kesatuan sikap, kesatuan dan juga kesatuan dalam tindakan. Dengan demikian, kerukunan antar umat beragama di masyarakat akan menyadari bahwa Negara adalah milik bersama. Oleh karena itu, kerukunan antar umat beragama bukanlah kerukan sementara, akan tetapi kenukunan yang hakiki yang dilandasi dan dijiwai oleh agama masing-masing masyarakat.

Setiap agama dan aliran kepercayaan yang ada memiliki ajaran serta budaya masing-masing dalam menjalankan ibadahnya, demikian pula dalam menjalankan peringatan hari raya agama yang sering dirayakan oleh setiap umat beragama. Momentum hari raya harus dimanfaatkan dengan sebaik-baiknya oleh setiap pemeluk agama yang sedang merayakannya. Selain itu, lanjutnya, bagi pemeluk agama yang yang tidak merayakan hari raya tersebut hendaknya dapat menghomati agama lainnya baik dengan sikap maupun dengan tindakan sehingga keharmonisan dalam kehidupan social bermasyarakat akan dapat terwujud demi untuk menjaga kerukunan antar umat beragama.

Dusun Sumbermanggis merupakan lokalitas re yang berada di wilayah Desa Barurejo kecamatan Siliragung Kabupaten Banyuwangi. Penelitian tentang kerukunan antar umat beragama pada masyarakat Dusun Sumbermanggis Desa Barurejo ini, dilandasi oleh ketertarikan penulis terhadap kondisi social yang tumbuh di Dusun Sumbermanggis Desa Barurejo.

Dusun Sumbermanggis juga merupakan salah satu miniature dari kehidupan beragama yang menjadi dambaan dan cita-cita bangsa yang memiliki berbagai macam agama. Masyarakat Dusum Sumbermanggis mempunyai beberapa agama yaitu : Islam, Hindu dan Kristen. Penganut masing-masing agama dan kepercayaan tersebut dapat hidup berdampingan dalam hidup bermasyarakat serta dapat memahami arti 
perbedaan, hal ini diwujudkan dengan kegiatan Sosial kemasyarakatan dalam peringatan hari raya besar keagamaan dengan cara saling berkunjung dan saling menghormati antar pemeluk agama yang lain. Hal tersebut merupakan fenomena Sosial yang menarik untuk diteliti, maka penelitian ini difokuskan kepada masalah bentuk-bentuk kerukunan antar umat beragama dalam memperingati hari-hari besar dalam keagamaan, Dalam Perspektif Sosiologi Agama.

Sesuai paparan diatas, maka penelitian ini di beri Judul "Perspektif Sosiologi Agama” (Kerukunan Antar Umat Beragama Dalam Peringatan Hari Besar Keagamaan (PHBA) di Dusun Sumbermanggis, Desa Barurejo, Keacamatan Siliragung Kabupaten Banyuwangi)

\section{B. Pembahasan}

\section{Kerukunan Antar Umat Beragama}

Kerukunan antar umat beragama merupakan dua proses komunikasi kerja sama antar umat beragama yang tidak dapat dipisahkan, sebab salah satu bagian dari kerukunan antar umat beragama adalah perlu adanya interaksi atau hubungan komunikasi antar agama. (Anang Muchtar Ghazali, 2004 : 209)

Sedangkan kalau dilihat secara etimologis kata kerukunan berasal dari bahasa arab, yaitu:" ruknun" berarti tiang, dasar, sila. Jamak ruknun adalah "arkaan"; artinya suatu bangunan sederhana yang terdiri dari berbagai unsur (asas). Dari kata ini akan diperoleh pengertian, bahwa kerukunan merupakan suatu kesatuan yang terdiri dari berbagai unsur yang berlainaan dan setiap unsur tersebut saling menguatkan. Kerukunan antar umat beragama bukan berarti meralitifir agama-agama yang ada dengan melebur kepada satu totalitas (sinkretisme agama) dengan menjadikan agama-agama yang ada itu sebagai cara atau sarana untuk mempertemukan, mengatur hubungan luar antara orang yang tidak seagama atau antara golongan umat beragama dalam setiap proses kehidupan sosial kemasyarakatan. Rukun dalam kehidupan agama dapat tercipta 
apabila tiap-tiap orang saling tenggang rasa dan lapang dada. (Ishomuddin, 2002 : 120).

Kerukunan artinya adanya suasana persaudaraan dan kebersamaan antara semua orang meskipun mereka berbeda secara suku, agama, ras dan golongan. Kerukunan juga bisa bermakna suatu proses untuk menjadi rukun, karena sebelumnya ada ketidakrukunan serta kemampuan dan kemauan untuk hidup bersama dengan damai dan tentram sejahtera.

Kerukunan juga diartikan sebagai kehidupan bersama yang diwarnai oleh suasana baik dan damai, hidup rukun berarti tidak bertengkar, melainkan bersatu hati, serta sepakat dalam berfikir dan bertindak demi mewujudkan kesejahteraan bersama. Didalam kerukunan semua orang bisa "hidup bersama tanpa kecurigaan, dimana tumbuh semangat dan sikap saling menghormati dan kesediaan untuk bekerja sama demi kepentingan bersama”. Kerukunan atau hidup rukun adalh sikap yang berasal dari lubuk hati yang terdalam, terpancar dari kemauan untuk memanng berinterkasi satu sama lain sebagai manusia tanpa tekanan dari pihak manapun.

Sementara dalam kaitan sosial, rukun diartikan denga adanya yang satu mendukung keberadaan yang lain. Dengan demikian kerukunan dalam konteks sosial merupakan norma yang sepatutnya diimplementasikan agar terwujudnya masyarakat madani yang saling peduli dan mendukung eksistensi masing-masing elemen masyarakat.

Allah Berfirman dalam Al-Qur'an Surah Al-Hujarat ayat 13:

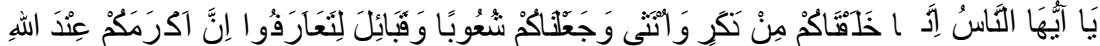

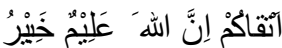

Artinya : "Hai manusia, sesungguhnya kami menciptakan kamu dari seorang laki-laki dan seorang perempuan dan menjadikan kamu berbangsa-bangsa dan bersuku-suku supaya kamu saling kenal mengenal. Karena sesungguhnya orang yang paling mulia diantara 
kamu disisi Allah ialah orang yang paling bertaqwa diantara kamu. Sesungguhnya Allah maha mengetahui lagi Maha mengenal," (QS. AlHujarat : 13).

Kata Syu'ub adalah bentuk jamak dari kata Sya'b. Kata ini menunjukkan kumpulan dari sekian qobilah yang biasa diterjemahkan suku yang menujuk kepada satu kakek. Qobilah atau suku pun terdiri dari sekian banyak kelompok yang dinamai bath. Dibawah bath ada sekiat fakhdz hingga akhirnya sampai himpunan keluarga yang terkeil.

Terlihat dari penggunaan kata, bahwa kata sya'b bukan menunjuk kepada pengertian bangsa, sebagaimana dipahami dewasa ini. Namun memang paham kebangsaan sebagai mana dikenal dewasa ini. Pertama muncul dan berkembang di Eropa XVIII M dan baru dikenal umat islam sejak masuknya Napolion ke mesir akhir abad XVIII tersebut. Namun, hal ini bukan berarti paham kebangsaan dalam pengertian modern tidak disetujui oleh Al-Qur'an. Bahkan disini tempatnya menguraikan hal tersebut.

Kata Ta’arafu terambil dari kata arafu yang berarti mengenal. Patron kata yang digunakan ayat ini mengandung makna timbale balik, dengan demikian berarti saling mengenal. Semakin kuat mengenal satu pihak kepada selainnya, maka semakin terbuka peluang untuk saling member manfa'at. Oleh karena itu, ayat diatas menekankan perlunya untuk saling mengenal satu dengan yang lain. Perkenalan itu sangat dibutuhkan untuk saling menarik pelajaran dan pengalaman pihk lainnya. Guna untuk meningkatkan ketaqwaan kepada Allah SWT yang dampaknya tercermin pada kedamaian serta kesejahteraan hidup duniawi dan kebahagiaan Ukhrowi. Bahkan tidak dapat bekerja sama tanpa saling kenal mengenal.

Demikian juga halnya dengan pengenalan terhadap alam raya ini. Semakin banyak pengenalan terhadapnya, maka semakin banyak pula rahasia-rahasia yang terungkap, dan ini gilirannya melahirkan 
kemajuan ilmu pengetahuan dan menciptakan kesejahteraan lahir dan batin, dunia dan untuk akhiratnya. (tafsir Quraish Shihab, hal 617-618).

Umat beragama adalah komunitas manusia yang mempercayai agama tertentu, pengikut atau penganut ajaran agama tertentu. Umat beragama muncul karena adanya sikap penghormatan terhadap Tuhan sebagaimana diajarkan dalam agama tersebut menjadi suatu system ajaran, tata hidup, dan kemasyarakatan. Maka di Indonesia misalnya teradapat beberapa penganut agama, yaitu diantaranya umat Islam, umat Kristen Protestan, umat Katolik, umat Hindu, umat Budha, dan Konghucu. Umat-umat beragama ini dapat saling bersaing dan saling bersaing dan saling menyerang kalau tidak ada keterbukaan terhadap penerimaan dan pengakuan adanyan agama lin. Tetapi dapat juga saling berdialog, saling memperdalam pengertian tentang diri dan masalah-masalah agama pada umumnya dan saling mendukung supaya Yang Maha Tinggi semakin dihormati menurut kemanusiaan yang adil dan beradab.

Manusia dalam kehidupan social bermasyarakat dengan keterbatasan mempunyai masalah-masalah yang serba komplek dan penuh dinamika dalam menjalin hubungan interaksi dengan sesame. Dalam memelihara keharmonisan hubungan antara sesamanya belum tentu berjalan dengan lancer. Utuk menjaga keharmonisan hubungan tersebut, maka Tuhan menurunkan agamasebagai pedoman dasar dalam mengatur suatu hubungan antara sesame manusia itu sendiri.

Dalam mewujudkan kemaslahatan umum, agama telah menggariskan dua pola dasar pokok hubungan yang harus dilakukan oleh pemeluknya, yakni : hubungan secara vertical dan hubungan secara horizontal. Yang pertama adalah hubungan antara pribadi dengan sang kholiqnya yang direalisasikan dengan bentuk ibadah, sebagaimana yang telah digariskan oleh setiap pemeluk agama itu 
sendiri. Hubungan ini dilaksanakan secara individu, namun ;ebih utama dilaksanakan secara kolektif. Pada hubungan pertama tersebut, berlaku hubungan toleransi agama yang hanya terbatas saja dalam lingkungan suatu agama. Sementara itu hubungan yang kedua adalah hubungan manusia dengan sesamanya. Pada lingkungan ini tidak hanya terbatas kepada agamanya saja, melainkan juga berlaku kepada orang yang tidak seagama, yaitu dalam bentuk kerjasama dalam masalah-masalah kemasyarakatan atau kemaslahatan umum.

Ibadah dalam pengertian luas tidak hanya terbatas kepada hubungan antara manusia dengan kholiqnya saja, namun juga meliputi dalam segala ucapan, perbuatan dan juga tindakan yang bernilai baik, seperti membangun masyarakat dan bangsa. Hal itu termasuk toleransi antar umat beragama.

Kehidupan beragama yang berkembang dengan subur, seperto pelaksanaan upacara-upacara keagamaan baik dalam bentuk ibadah atau ritual, maupun dalam bentuk peringatan, tidak hanya terbatas pada rumah-rumah atau tempat resmi masing-masing agama, namun juga pada tempat-tempat lain. Maka disinilah berlakunya toleransi terhadap umat beragama yang berlainan keyakinan.

Kerukunan dan toleransi dalam pergaulan hidup antar umat beragama merupakan bagian usaha untuk menciptakan keamanan, kelancaran serta kesejahteraan antara hubungan umat manusia yang berlainan agama, sehingga setiap golongan umat beragama dapat melaksanakan bagian dan tuntutan agama masing-masing.

Konsep kerukunan antar umat beragama pernah dirumuskan dan ditetapkan oleh pemerintah Orde Baru dengan melibatkan semua tokoh agama yang ada di wilayah tersebut. Selama masa Orba, relative tidak ada konflik antar pemeluk agama yang berbeda.

Agar kerukunan hidup antar umat beragama menjadi etika dalam pergaulan kehidupan baragama, Hugh Goddard, seorang Kristiani Inggris, yang ahli teologi islam mengingatkan, demi 
kerukunan antar umat beragama, maka diharuskan menghindari penggunaan "standar ganda" (double standars). Orang-orang Kristen ataupun islam, misalnya, selalu menerapkan standar-standar yang berbeda untuk dirinya; biasanya standar yang ditunjukkan bersifat ideal dan normative. Sedangkan terhadap agama lain, mereka memakai standar lain yang lebih bersifat realistis dan historis. Melalui standar ganda inilah muncul prasangka-prasangka teologis yang selanjutnya memperkeruh suasana hubungan antar umat beragama. Ada tidaknya keselamatan dalam agama lain, seringkali ditentukan oleh pandangan mengenai standar ganda kita. Keyakinan bahwa agama sendiri yang yang paling benar, karena berasal dari Tuhan, sedangkan agama lain hanyalah kontruksi manusia. (Dadang Kahmad, 2006 : 175-176)

Pengertian umat beragama adalah terbinanya keseimbangan antar hak dan kewajiban dari umat beragama. Keseimbangan antar hak dan kewajiban itu adalah hak yang sungguh-sungguh dari setiap penganut agama untuk meramalkan selunuh ajaran agamanya, sehingga ia menjadi agamawan paripurna, namun pada saat yang sama pengalaman ajaran agamanya tidak bersinggungan dengan kepentingan orang lainyang juga memiliki hak untuk mengamlkan ajaran agamanya (Said Agil Husain Almunawar, 2004 : 53)

Membangun kerukunan antar umat beragama adalah suatu kemestian yang tidak bias untuk ditawar-tawar. Karena hal ini disebabkan oleh ajaran-ajaran agama itu sendiri yang tidak mengajarkan penganutnya untuk memusuhi agama yang lainnya. Sungguh pun tidak mensepakati ajaran agama yang lain itu sendiri. Sepantasnya masing-masing penganut agama rela hidup berdampingan dengan bekerja sama untuk membangun masyarakat. Oleh karena itu program membangun masyarakat ini adalah untuk kepentingan bersama, maka adanya bentuk-bentuk kerja sama itu hendaknya dimulai dari hal-hal yang kongkrit yang dirasakan oleh 
semua orang tanpa memandang latar belakang agama dan budayanya tersebut.

Dalam menciptakan hidup bersama secara harmonis, maka dikalangan umat yang berbeda agama harus mempunyai dua bentuk sikap yang mana sikap itu adaah salah satu pondasi kerukunan :

Pertama, harus saling menghargai dan juga menghormati itu berjalan secara tidak 'sadar'. Artinya seseorang tersebut menghormati orang yang beragama lain, entah itu dalam segi apapun, terlebih dalam segi kepentingan social, ekonomi, politik dan juga budaya. Karena hal tersebut akan menunjukkan kerukunan, ketenangan, keamanan, serta kesejahteraan antar umat beragama itu sendiri. Misalnya segi kepentingan politik, karena sama-sama satu bangsa dan Negara, maka sepantasnya umat beragama harus saling rukun demi cita-cita yang adil dan makmur.

Kedua, yakni saling memberikan penghormatan terhadap orang yang menganut agama lain, bukan hanya karena kepentingan politik saja, namun labih dari hal politik itu, karena adanya kesadaran, bahwa agama-agama yang dianut manusia dibumi ini memiliki titik temu yang sangat mendasar.

Bentuk sikap yang pertama diatas seringkali dibina secara dialog dan mengusahakan saling tenggang rasa serta menabukan masalah sara. Tetapi perlu disadari bahwa sikap seperti ini sering kali lebih dangkal da sangat mudah untuk untuk terpancing jika terusik emosi keagamaannya, bahkan seringkali mengorbankan cita-cita bersama, hanya karena ketersinggungan emosi keagamaan.

Bentuk sikap yang kedua yakni sangat mendasar dan tak mudah untuk terpancing, namun apabila terprovokasi, maka akan menjadi dampak yang sangat besar bagi agama tersebut, karena adanya politik yang menjadi sasaran provokator.

Menurut Said Agil Husain Almunawar (2004 : 5) mengatakan, bahwa dengan kerukunan antar umat beragama yang dimaksud 
adalah, agar terbinanya dan terjaga hubungan baik dalam pergaulan antara warga yang berlainan agama. Urgensi kerukunan adalah untuk mewujudkan kesatuan pendangan yang membutuhkan kesatuan sikap guna melahirkan kesatuan perbuatan dan tindakan. Sedangkan kesatuan perbuatan dan tindakan menanamkan rasa tanggung jawab atau tidak menyalahkan pihak lain. Dengan kerukunan antar umat beragama, maka masyarakat menyadari bahwa Negara adalah milik bersama dan merupakan tanggung jawab bersama umat beragama, karena itu antar umat beragama bukanlah kerukunan sementara, bukan kerukunan politisi, namun krukunan yang hakiki yang dilandasi dan dijiwai oleh agama masing-masing.

Dalam pengertian sehari-hari kata rukun dan kerukunan adalah damai dan perdamaian, dengan pengertian jelas bahwa kerukunan hanya dipergunakan dan berlaku dalam dunia pergaulan. Kerukunan yang berpegang kepada prinsip masing-masing agama yang menjadikan setiap golongan umat beragama sebagai golongan yang sangat terbuka, sehingga memungkinkan untuk saling melakukan interaksi apabila anggota dari suatu golongan umat beragama telah berhubungan baik dengan umat beragama yang lainnya. Maka akan memungkinkan untuk mengembangkan hubungan dalam berbagai bentuk kerjasama yang saling menguntungkan dan tidak ada satu pihak pun yang dirugikan.

Kerukunan antar umat beragama dapat diwujudkan dengan hubungan sesama umat yang didasari toleransi, saling menghormati, menghargai perbedaan keyakinan, pengamalan ajara agamanya dan kerja sama dalam kehidupan bermasyarakat, berbangsa dan bernegara.

Dalam masyarakat yang multiagama, Harold Howard (Saefullah, 2007 : 180) mengatakan ada tiga prinsip umum dalam merespons keanekaragaman agama : Pertama, logika bersama, yang satu yang berwujud banyak. Secara filosofis dan teologis, logika ini merupakan 
sumber realitas dan cara paling signifikan untuk menjelaskan keanekaragaman agama. Bagi mereka yang mendalami sejarah agama-agama, logika ini bukanlah hal yang asing. Misalnya, dalam veda dapat menemukan gagasan tentang yang satu yang disebut dengan banyak nama. Kedua,agama sebagai alat. Karenanya, wahyu dan doktrin dari agama-agama adalah jalan, atau dalam tradisi islam disebut syari'at untyk menuju yang satu. Karena sebagai alat, yang ada dalam agama-agama adalah kumpulan particular sarana yang digunakan sebagai alat yang dengannya yang satu dapat dicapai. Ketiga, pengenaan kriteria yang mengabsahkan. Yang dimaksud adalah mengenakan kriteria sendiri pada agama-agama lain. AlQur'an menupakan wahyu yang mengabsahkan, sehingga menjadi dasar untuk menguji wahyu-wahyu lainnya. Maka dengan kriteria tersebut masing-masing digunakan untuk menuju Yang Satu.

Kerukunan beragama berkaitan dengan toleransi, yakni istilah dalam konteks social, budaya, dan agama yang berarti sikap dan perbuatan yang melarang adanya diskriminasi terhadap kelompokkelompok yang berbeda atau tidak dapat diterima oleh mayoritas dalam suatu masyarakat. Contohnya adalah toleransi beragama, dimana penganut mayoritas dlam suatu masyarakat mengizinkan keberadaan agama-agama lainnya.

Ketidak harmonisan antar pemeluk agama dilator belakangi oleh banyaknya faktor. Secara kategoris simplistic hal itu dapat dibedakan menjadi du faktor, yaitu faktor internal dan eksternal. Faktor internal adalah faktor yang mempengaruhi seseorang bersikap yang disebabkan paham keagamaan terhadap ajaran agamanya tersebut. Konflik antar umat beragama itu sering terjadi dan merupakan faktor pembakar emosional umat yang paling cepat dalam memunculkan konflik. Dengan demikian, kerukunan menjadi bahan kajian antar umat beragama untuk memutuskan konsep membina kerukunan, 
sehingga konflik yang bersumber dari faktor agama dapat meredam sedini mungkin.

Keberhasilan dalam membangun masyarakat salah satunya dilandasi dengan terciptanya kerukunan di tengah-tengah masyarakat yang pluralis. Untuk menyikapi pluralitas agama agama tersebut. Paling tidak, ada dua pertanyaan besar bagi pemeluk agama: Pertama, bagaimana memposisikan diri di tengah-tengah pluralitas agama. Kedaua, bagaimana teologi suatu agama mendefinisikan diri di tengah-tengah agama lain. Hal tersebut dimaksudkan agar agama benar-benar berfungsi sebagai faktor pemersatu (integrated factor) dalam masyarakat yang majemuk, sehingga tidak saling berbenturan.

Menyikapi problem diatas, maka ada beberapa hal yang perlu tidak direalisasikan oleh pemeluk agama, yaitu antara lain :

Pertama, memposisikan diri sebagai pemeluk suatu agama dengan benar. Benar disini maksudnya adalah sesuai undang-undang yang berlaku dan hak asasi masing-masing. Sangat tidak bisa dibenarkan tindakan-tindakan menyimpang seperti pemaksaan, penipuan, ,istik, terlebih dilakukan kepada orang yang sudah memeluk suatu agama tertentu, sebab sikap-sikap seperti ini akan menimbulkan emosioanl pemeluk agam lain. Jadi, penyebaran agama harus dilakukan dengan pola yang arif dan adil (fail play).

Kedua,mendefinisikan teologi keagamaan yang bermuara pada konteks pluralitas. Artinya, meminimalisir bahasa absolutisme, eksklusivisme, ekstrimisme dan agresivisme dalam berinteraksi dengan pemeluk antar umat beragama. Absolutisme adalah kesombongan intelektual. Eksklusivisme adalah kesombongan sosial. Fanatisme adalah kesombongan emosional. Ekstrimisme adalah berlebih-lebihan dalam bersikap, dan Agresivisme adalah berlebihlebihan dalam tindakan fisik. Tidak bisa dipungkiri bahwa setiap agama memiliki klaim kebenaran (truth claim). 
Ketiga, reinterprestasi pesan-pesan agama, semua agama harus mampu memerankan fungsinya menjadi dialektis konstruktif. Bahasa-bahasa agama (dogma) harus diwujudkan dalam bentuk teori-teori sosial yang dapat diaplikasikan atau lebih tepatnya harus di kontekstualisasikan agar berfungsi historis, dan membumi. Pencerahan terhadap masyarakat melalui upaya reinterprestasi agama, sehingga pesan-pesan agama menjadi fungsional. Yang akhirnya ajaran keadilan, toleransi, dan cinta kasih yang terkandung dalam agama menjadi implementatif dan integrative dalam kehidupan bermasyarakat dan berbangsa.

Keempat, dialog antar umat beragama, hal ini sangat perlu untuk dilakukan, agar komunikasi antar pemeluk umat beragama yang diwakili oleh pemuka-pemukanya terjalin dengan baik. Untuk itu, setiap pemeluk agama harus bersikap terbuka, sehingga terwujud dialog yang kontruktif.

Kelima, saling menghormati dan saling menghargai. Jadi, setiap umat beragama harus memunculkan sikap tersebut dan bertekad untuk terus menjaga suasana agar tetap damai.

Setiap bangsa selalu emngidam-idamkan masyarakat yang aman, damai dan tentram. Tidak ada agama yang mengajarkan umatnya untuk menciptakan kekacauan daam kehidupan di dunia ini. Untuk itu, hendaknya semua pemeluk agama bertekad untuk benar-benar memfungsikan agam sebagai faktor pemersatu bangsa dengan senantiasa membina kerukunan antar umat beragama.

Pemerintah bersama masyarakat sepakat menggunakan istilah kerukunan dengan konsep kerukunan hidup beragama yang menakup kerukunan interen umat beragama (kondisi rukun dalam satu agama), kerukunan antar umat beragama (kondisi rukun antar umat yang berbeda-beda agama), dan kenukunan antara (pemuka) umat beragama dan pemerintah. Dialog interen umat beragama merupakan bagian tidak terpisahkan dari Tri kerukunan kehidupan 
umat beragama, yang pada dasarnya merupakan upaya mempertemukan hati dan pikiran dikalangan sesame penganut agama. Secara umum pemimpin agama berperan penting dalam merancang dan melaksanakan dialog interen umat beragama, antar umat beragama, dan antara umat beragama dan pemerintah, baik dari kalangan pemuka agama, ulama cendekiawan muslim, mubaligh, maupun pemimpin kelompok keagamaan dari kalangan penganut dan pemimpin agama lainnya.

\section{Peringatan Hari Besar Keagamaan (PHBA)}

Setiap agama pasti mempunyai hari yang dimuliakan atau hari raya dan mempunyai tradisi serta cara masing-masing dalam merayakan hari besarnya tersebut. Seara garis besar, hari raya tersebut memiliki dua makna religious, yaitu : Pertama, sebagai media pendekatan dan pelayanan terhadap Tuhan Yang Maha Esa. Kedua, sebagai media untuk penyucian diri.

\section{Bentuk Kerukunan Dalam Peringatan Hari Besar Keagamaan}

\section{a. Komunikasi (Saling Berkunjung/Silaturrahim)}

Silaturrahmi adalah istilah yang cukup akrab dan popular di dalam pergaulan umat Islam sehari-hari, namun pada hakekatnya istilah tersebut merupakan bentukan dari bahasa Arab dari kata silaturrahim, dan istilah silaturrahim ini berasal dari dua kata yakni : Shilah yang berarti hubungan atau sambungan, dan rahim yang memiliki arti peranakan.

Silaturahmi adalah tradisi saling mengunjungi atau berkunjung kepada saudara, kerabat, atau sahabat agar hubungan kekeluargaan, kekerabatan, dan persahabatan tidak terputus.

Arti Silaturahmi secara umum adalah : Menghubungkan tali kekerabatan, atau menghubungkan kasih saying dengan cara saling berkunjung terutama terhadap saudara atau anggota keluarga sendiri bahkan 
terhadap tetangga atau saudara seiman. (http://www. Pengertian-saling-silaturrohim.com diakses pada 14 juli 2019)

\section{b. Interaksi (Saling Menghargai dan Mengormati)}

Menghargai adalah sikap atau salah satu cara untuk memberi penilaian, menghormati, penentuan atau memandang penting seseorang atau karya seseorang. Sikap menghargai juga harus dimiliki pada setiap manusia agar terciptanya keserasian dan kerukunan hidup antarmanusia sehingga terwujudlah kehidupan masyarakat yang saling menghargai satu sama lain. Menghargai juga dapat berarti menghormati keberadaan, harkat dan martabat orang lain.

Contoh dari menghargai adalah menghargai karya orang lain, artinya menghormati hasil usaha, ciptaan, dan pemikiran orang lain. Kita wajib menghargai hasil karya orang lain, karena dengan sikap seperti itu kehidupan akan berjalan dengan tentram dan damai karena setiap orang akan menyadari pentingnya sikap saling menghargai tersebut.

Dengan menghargai orang lain, maka orang lain akan menghargai kita. Memberikan penghargaan pada orang lain berarti kita telah berperilaku terpuji. Menjauhkan diri dari sikap menghina, mencela, dan mengejek, hasil karya orang lain maka kita membuat orang lain senang dan gembira karena hasil karyanya dihargai.

Sedangkan Menghormati adalah sikap dimana kita memperlakukan seseorang dengan sepantasnya dan pada tempatnya. Dalam kehidupan sehari-hari sikap menghormati ini sangat penting karena merupakan akhlak yang baik bagi manusia sebagai makhluk sosial. Dimana kita harus berinteraksi dengan baik kepada sesama. Selain itu, menghormati berarti melayani dengan penuh sopan, menjunjung tinggi, memuliakan, menerima dan mematuhi. 
(http://www. Pengertian-menghargai-dan menghormati.com diakses 14 Juli 2019).

\section{Kesimpulan}

Temuan bentuk-bentuk data dari Kerukunan Antar Umat Beragama yaitu : Interaksi dan Komunikasi. Hal tersebut menyangkut teori dari Kerukunan antar umat beragama yang tidak dapat dipisahkan, sebab salah satu bagian dari kerukunan antar umat beragama adalah perlu adanya interaksi dan hubungan komunikasi antar agama. (Anang Muchtar Ghazali, 2004 : 209)

Dengan demikian, kerukunan antar umat beragama dalam peringatan hari besar keagamaan di Dusun Sumbermanggis, Desa Barurejo, Kecamatan Siliragung, Kabupaten Banyuwangi adalah : Interaksi yang diwujudkan dengan adanya saling menghargai serta menghormati ketika salah satu agama ada yang memperingati hari besar keagamaan, dan Hubungan komunikasi yang diwujudkan dengan saling silaturrohim serta saling sambang kerumah warga yang berbeda agama yang sedang melaksanakan hari besar keagamaan.

\section{Daftar Pustaka}

Kahmad, Dadang, 2002. Sosiologi Agama, Bandung : PT. Remaja Rosda Karya.

Hendropuspito, 2006. Sosiologi Agama, Yogyakarta, PT. Kanisius.

Mulyana, Deddy, 2003. Metode Penelitian Kualitatif Paradigma Baru Ilmu Komunikasi Dan Ilmu Sosial Lainnya, Bandung: PT. remaja rosdakarya.

Hamidi, 2004. Metode Penelitian Kualitatif, Malang, Universitas Muhammadiyah Malang.

Haryono, Suyono, 2007. Pedoman Pembentukan dan Pengembangan pos pemberdayaan Keluarga. Jakarta.

Arikunto, Suharsimi, 2006. Prosedur Penelitian Suatu Pendekatan Praktik, Jakarta : PT. Rineka Cipta.

Ali, aziz Muhammad, 2006. Ilmu Dakwah, Jakarta : PT. Prenada media.

Husain, Al-Munawar, Said Agil, 2003. Agenda Generasi Intelektual. Jakarta: Pena Madini.

Bahtiar, Effendy, 2002. Masyarakat Agama Dan Pluralisme Keagamaan, Yogyakarta : PT. Galang Press.

38 | Perspektif Sosiologi Agama” (Kerukunan Antar Umat Beragama Dalam Peringatan Hari Besar Keagamaan (PHBA) 
Mardalis, 2006. Metode penelitian pendekatan Proposal. Jakarta: Bumi Aksara.

Shihab, M.Quraish, 2009. Ma'had al-Furqon, Sidayu, Gresik.

Ms, Basri. 2006. Metodelogi Penelitian Sejarah. Restu Agung.

Narwoko, J. Dwi. 2006. Sosiologi: Teks Pengantar dan Terapan. Jakarta: Kencana Prenada Media Group.

Adeng, Mukhtar Ghazali, 2004. Antropologi Agama, Jakarta : PT. Pustaka.

Bachtiar, wardi, 1997. Metodologi Penelitian Ilmu Dakwah, Jakarta : PT. Logos Wacana Ilmu.

Bungin, Burhan, 2007. Sosiologi Komunikasi Teeori Paradigma Dan Diskursus Teknologi Komunikasi Di Masyarakat, Jakarta : PT. Kencana.

Gerungan, 2004. Psikologi Sosial, Bandung : PT. Redika Aditama.

Ishomuddin, 2002. Pengantar Sosiologi Agama, Jakarta, PT. Galio Indonesia. Partanto, 1994. Pius, Kamus Ilmiah Popular, Surabaya : PT. Arkola.

Pawito, 2007. Penelitian Komunikasi Kualitatif, Yogyakarta PT. LKiS Pelangi Aksara,

Polak, Maijor, 1982. Sosiologi: Suatu Pengantar Riskas. Jakarta: PT. Ichtiar Baru.

Rujukan Internet/ Elektronik

http://Pengertian-hari-raya-idul-fitri.com, diakses 14 Juli 2019

http://Idul-Adha.com, diakses 14 Juli 2019

http://Pengertian-Isra' Mi'raj.com diakses 14 juli 2019

http://pengertian-maulid-nabi-muhammad/.com, diakses 14 Juli 2019

http:// Makna-hari-raya-nyepi.com diakses 14 Juli 2019

http://Hari-raya-saraswati.com diakses 4 Juli 2019

http://Makna-Galungan.com diakses 14 Juli 2019

http://Hari Raya Kuningan.com diakses 14 Juli 2019

http://Makna-jumat-agung.com diakses 14 juli 2019

http://Makna-hari-raya-paskah-bagi-umat-katolik-dan-kristen diakses 14 juli 2019

http://Hari-raya-Natal.com di akses pada 14 juli 2019

http://Pengertian-saling-silaturrohim.com diakses pada 14 juli 2019

http://Pengertian-menghargai-dan menghormati.com diakses 14 Juli 2019

39 | Perspektif Sosiologi Agama" (Kerukunan Antar Umat Beragama Dalam Peringatan Hari Besar Keagamaan (PHBA) 